\title{
Monitoring the Morphodynamic Cannibalization of the Rossbeigh Coastal Barrier and Dune System over a 19-Year Period (2001-2019)
}

\author{
Siegmund Nuyts ${ }^{1}$, Michael $\mathrm{O}^{\prime}$ Shea ${ }^{1, *(\mathbb{C})}$ and Jimmy Murphy ${ }^{1}$ (D) \\ Environmental Research Institute, Beaufort Building, MaREI Centre, Cork P43 C573, Ireland; \\ Siegmund.nuyts@ucc.ie (S.N.); jimmy.murphy@ucc.ie (J.M.) \\ * Correspondence: michaeloshea@ucc.ie
}

Received: 25 May 2020; Accepted: 7 June 2020; Published: 9 June 2020

check for updates

\begin{abstract}
This research presents a study on the morphodynamic evolution of the Rossbeigh coastal barrier and its dune system, located in Dingle Bay, County Kerry, Ireland. The study examines the evolution of the system over a 19-year period (2001-2019) through remote sensing, geographic information system (GIS) analysis, and field-based surveys. This research provides an ideal opportunity to examine a natural erosion event, referred to as cannibalization on a coastal barrier and its dune system. Since the beginning of this century, significant erosion has been visible on the coastal barrier, with the erosion eventually leading to a breaching event in the winter of 2008/2009. Over the study period, analysis has shown that the vegetated dunes decreased by more than 60 percent, the width of the breached area reached a maximum width of over $1 \mathrm{~km}$ and a change in orientation and appearance on the coastal barrier has been quantified. The analysis identifies a growing drift-aligned zone, contrasted with a reduction in the stable swash-aligned zone. Significantly, the point between these zones (i.e., the hinge point) has been shown to have moved by more than $1 \mathrm{~km}$ also. The migration of this hinge point and cannibalization of the dunes are illustrated. Finally, the potential mechanism for beach healing is identified, utilizing the rich datasets collected during the study, thus providing an insight into the long-term behavior of a dynamic coastal barrier system undergoing naturally driven cannibalization.
\end{abstract}

Keywords: coastal dunes; barrier dynamics; overwash; coastal erosion; dune cannibalization

\section{Introduction}

Coastal barriers are narrow, elevated ridges of sand or gravel, often parallel to the shore. The dune systems on sand based coastal barriers play an important role in the coastal environment as they protect the exposed coastlines from open-ocean forcings [1-3]. This also makes them one of the most vulnerable coastal systems. For example, breaching events of the dune system can occur under extreme weather events and after several erosion cycles. Breaching events around the world have been widely reported by [4-7]. Often, these breaching events include human intervention in order to re-establish the dune systems, such as mechanical breach closure, beach scraping, and sediment bypassing systems. Understanding the different processes involved after a breaching event occurred is fundamental for an adequate management of coastal barriers and their dune system.

The spatial and temporal patterns of open-ocean forcings are responsible for the changes prevalent on coastal barriers and dune systems. These include: (1) littoral processes (i.e., the movement of sediment along the coastal region by currents primarily induced by waves and tides); (2) aeolian processes (i.e., transporting wind regime) [8-11]; and (3) other sedimentary factors (e.g., sediment budget, vegetation, backshore budget, and barrier dynamics). 
The magnitude and direction of these processes have an influence on the morphology, which could lead to erosion and eventually the breaching of the dune systems on coastal barriers [12]. It is therefore essential to examine the factors that control the spatial and temporal patterns of erosion on dunes and their accretion. These control factors are relatively well understood on small timescales [13-16], whereas their influence and changes in medium and long-term timescale are less clear. As such, it is critical to develop a better understanding of the morphodynamics and hydrodynamics of dune systems for the prediction of the long-term behavior of such systems.

The aim of this study is to understand the drivers and consequences of a natural cannibalizing process. [17] stated that the breaching of a coastal barrier and its dunes can be divided into two different processes: (1) macro-cannibalization and (2) micro-cannibalization. These processes of cannibalization include the change in orientation and the evolution of alignment on coastal barriers. Micro-cannibalization is usually the result of along-shore sediment transport, where the erosion is localized in smaller sub-cells and often results in a breaching event. Contrary to the sub-cell erosion rates of micro-cannibalization, macro-cannibalization is experienced over the entire length of a coastal barrier and its dunes. This is mainly caused by a change in the sediment supply regime and often indicates a change in orientation (i.e., from drift-aligned zone to a swash-aligned zone or vice versa). Both processes have been identified as mechanisms during the evolution of the coastal barrier in Rossbeigh.

This study evaluates the evolution of the dune system on the Rossbeigh coastal barrier over a period of 19 years (2001-2019) with a particular emphasis on the processes prevalent on the coastal barrier and its surrounding coastal cell. The study is a rare opportunity to investigate a natural breaching event as it includes significant datasets from both before and after the breaching event. This enables the authors to undertake an in-depth evolutionary analysis of the system. A collation of the storm events occurring in the study area since 1995 provides context to the drivers that led to the changes in the coastal cell that includes Rossbeigh. The evolution is documented through the analysis of both remotely sensed data and field-based data utilizing GIS tools.

\section{Study Area}

The Rossbeigh coastal barrier is situated in Dingle Bay, County Kerry, Ireland. It is in the south-western part of Ireland, with longitude around: $9^{\circ} 58^{\prime} 0^{\prime \prime} \mathrm{W}$ and latitude around: $52^{\circ} 05^{\prime} 00^{\prime \prime} \mathrm{N}$. The bay is around $18 \mathrm{~km}$ wide and $42 \mathrm{~km}$ long, and consists of three mid-bay barriers: Rossbeigh, Inch, and Cromane (Figure 1). There is a fast-flowing channel between Inch and Rossbeigh of approximately $2 \mathrm{~km}$ in width, where tidal currents can reach over $1 \mathrm{~m} / \mathrm{s}$ at peak floods, and an expansive ebb tidal delta at the northern (distal) point of Rossbeigh [18]. The tidal inlet between Inch and Rossbeigh acts as an important driver of sediment transport. Dingle Bay itself is characterized as mesotidal, with a spring tidal range of approximately $3.2 \mathrm{~m}$. The mean significant wave height $(\mathrm{Hs})$ is $2.8 \mathrm{~m}$, with an average wave period of $\mathrm{Tp}=7 \mathrm{~s}$, taken over a 50-year period of storm data analysis from the M3 wave buoy, located $100 \mathrm{~km}$ from the study area $\left(51.2166^{\circ} \mathrm{N}, 10.5500^{\circ} \mathrm{W}\right)($ Sala, 2010). Because Dingle Bay is relatively narrow and bounded by two rocky headlands, the morphology is only affected by a small band of wave forcing, ranging from $225^{\circ}$ to $315^{\circ}$. Wind forcing incidents in the bay are predominantly south westerly, as documented in [19]. [19] also classified the coastal cell as a mixed wave/tide dominated to tide dominated system based on [20] and as a self-contained system (i.e., the sediment transport is conserved within the bay itself). Sediment grain size analysis on Inch and Rossbeigh $[21,22]$ indicates that sediments are relatively homogenous with a $D_{50}$ in the range of $260 \mu \mathrm{m}$. 


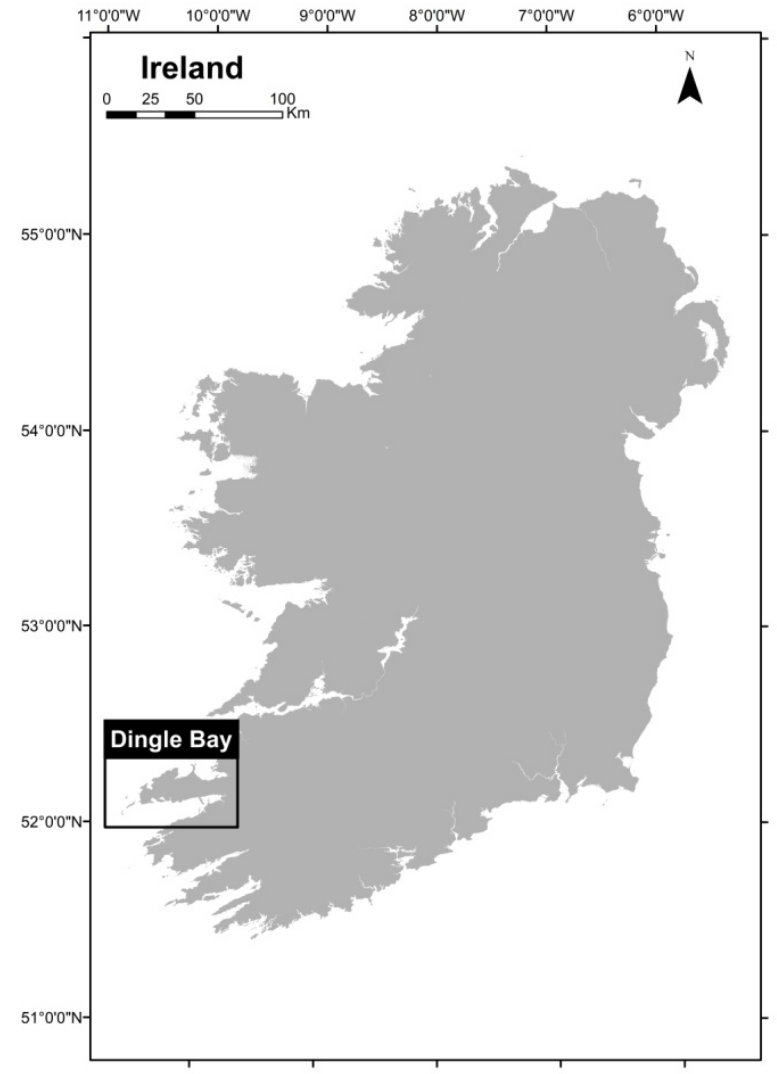

(a)Study Area Location

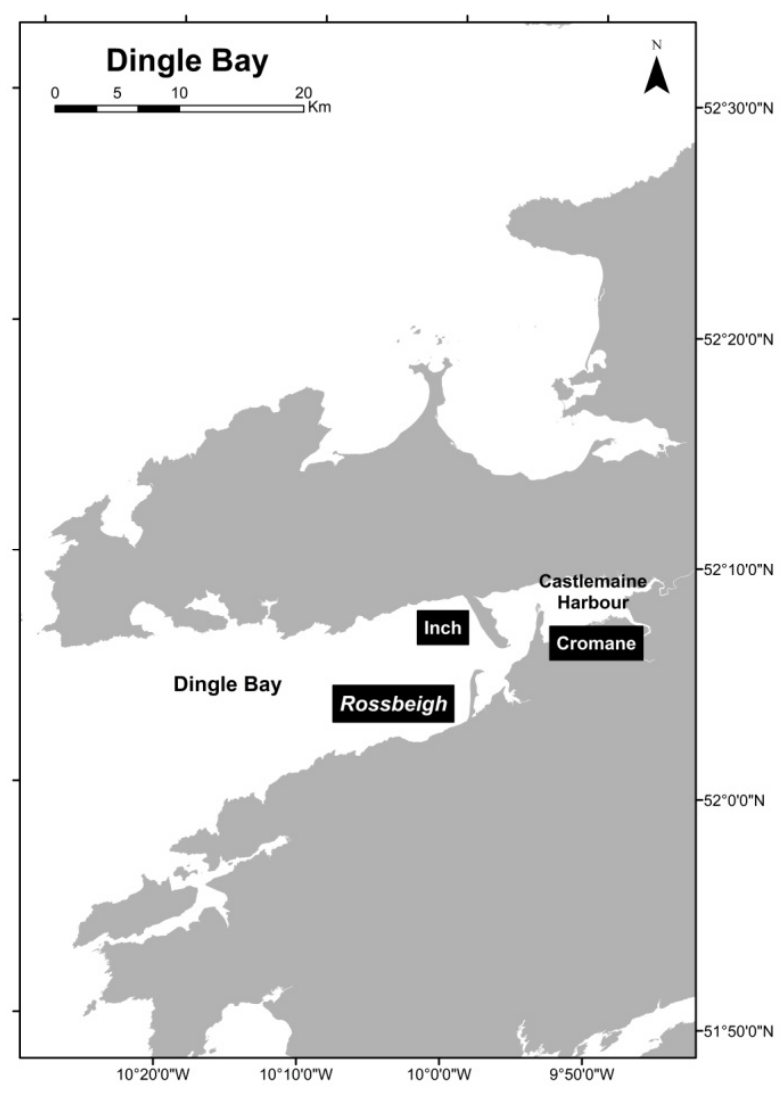

(b) Dingle Bay

Figure 1. Study Site.

This work focuses exclusively on the Rossbeigh coastal barrier and its dunes. The Rossbeigh coastal barrier extends northwards from the southern shore of Dingle Bay as a relatively stable swash-aligned zone for approximately $3 \mathrm{~km}$ (in 2001). The orientation changes and becomes drift-aligned thereafter for approximately $2 \mathrm{~km}$. The drift aligned section of the beach has been shown to be less stable and subject to strong erosion $[20,23]$. It was [24] that introduced the distinction between these alignments when referring to coastal barriers and beaches and defined their typical properties in terms of evolutionary features i.e., (1) swash-aligned coasts and (2) drift-aligned coasts. The main difference between these two types of coasts is the wave approach perpendicular (1) or an oblique wave approach (2). These distinctions apply to beaches that have no well-developed wave-formed slope on the landward side [25]. The differences in zones are driven by the presence of long-shore drift rates (i.e., drift-aligned zone) or a lack of them (i.e., swash-aligned zone).

The width of the present day Rossbeigh barrier system varies between $100 \mathrm{~m}$ and $600 \mathrm{~m}$ (Figure 2), and vegetated dunes are present along most of the barrier, apart from the breached area in the drift-aligned zone since the winter of 2008/2009. The barrier itself consists of a sand dune system partially superimposed on a cobble or gravel ridge basement, with the coarser materials acting as an anchor upon which the finer sediments move. The dunes consist of undulating vegetated sand hills on the proximal part (i.e., the section of the coastal barrier attached to the mainland) of the system, with blowouts and low linear foredune ridges fronting the distal part (i.e., the northern section of the coastal barrier on the open coast side). In this case, the proximal part of the coastal barrier is characterized as a swash-aligned zone and the distal part as a drift-aligned zone. 

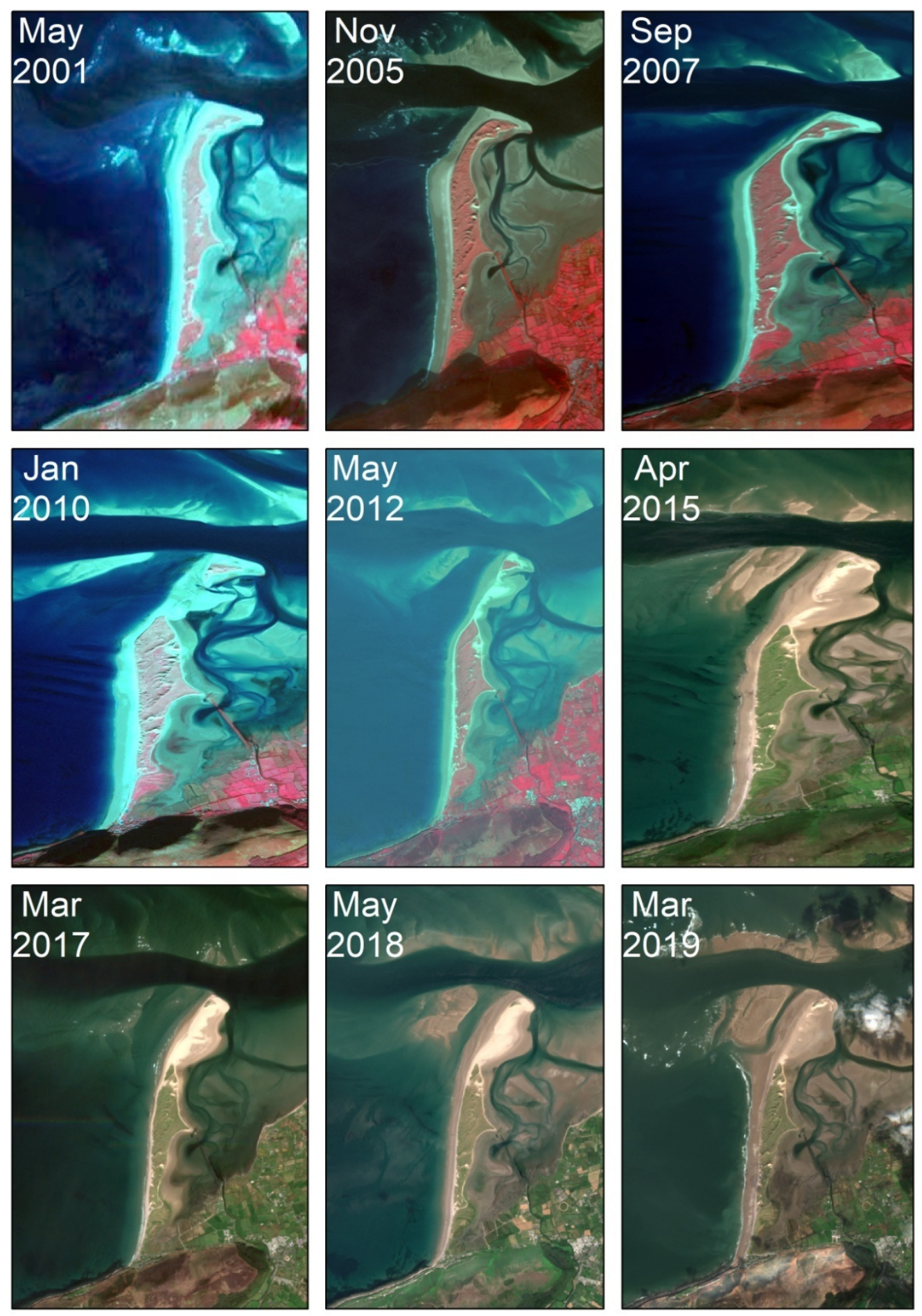

Figure 2. Barrier alignment.

Dune heights in the swash-aligned zone range between $12 \mathrm{~m}$ and $17 \mathrm{~m}$ above mean sea-level. In the drift-aligned zone, the dune heights decline to values between $5 \mathrm{~m}$ and $12 \mathrm{~m}$ above mean sea-level. Due to exposure to modally high energy, fully-refracted swell, and the availability of sandy sediment in the drift-aligned zone, the distal part of the coastal barrier is characterized by shallow cross-shore gradients and can be classified as unbarred, dissipative, flat, and featureless, where spilling breakers are dominant $[26,27]$. 
In the winter of 2008/2009 a breaching event occurred in the drift-aligned zone of the coastal barrier. This breaching event was the result of continuous erosion from previous years and increased hydraulic forcing by storm surges and waves. This can be described as overwash and is defined as the flow of water and sediment across the crest of the beach/dune that does not directly return to the water body where it originated [28-31]. A breaching event generally takes place in a relatively short time (less than eight hours) [6].

\section{Methods}

The methodologies utilized in this study include collection and analysis of remotely sensed data, topographic surveying, bathymetric monitoring, and storm event analysis in the study area. The datasets vary in length and temporal resolution, but the majority of analysis focuses on the period since 1995.

\subsection{Remote Sensing}

Both quantitative and qualitative analysis of the evolution of the coastal barrier in Rossbeigh was carried out with satellite images. The raw images were first imported into an image processing software (i.e., ENVI), which combines advanced image processing and geospatial analysis technology. After initial image processing (e.g., orthorectification and image enhancement), the new data was imported into GIS (i.e., ArcMap 10.6), allowing the visualization of change over time. Table 1 gives an overview of the images used for the analysis. The outline of the coastal barrier in 2001 is used as a reference to show the different changes occurring on the coastal barrier and its surrounding coastal cell.

Table 1. Satellite images used for the analysis of the study area.

\begin{tabular}{cccc}
\hline \multicolumn{4}{c}{ Satellite Images Rossbeigh } \\
\hline Date & Satellite & Sensor & Resolution $(\mathbf{m})$ \\
\hline 21 May 2001 & SPOT 4 & HRVIR & 20 \\
17 November 2005 & SPOT 5 & HRG & 10 \\
09 September 2007 & SPOT 5 & HRG & 10 \\
20 January 2010 & SPOT 5 & HRG & 10 \\
25 May 2012 & SPOT 5 & HRG & 10 \\
17 April 2015 & Pleiades & Pleiades 1A & 0.5 \\
25 March 2017 & Sentinel 2 & S2A & 10 \\
16 May 2018 & Sentinel 2 & S2A & 10 \\
25 March 2019 & Sentinel 2 & S2A & 10 \\
\hline
\end{tabular}

After analyzing the different images, it was clear that significant erosion occurred on the coastal barrier and its dune system. Thus, it was decided to undertake field-based data collection, including topographical and bathymetric surveys.

\subsection{Topographical and Bathymetry Survey}

The topographical surveys were completed with three different devices, over different dates. All the equipment used ((1) LEICA 1200; (2) Trimble Ranger 2; and (3) LEICA Viva Rover GS08) use the RTK-GPS method. These devices are global navigation satellite system (GNSS) technologies that track all existing satellite signals, including GPS and GLONASS.

A total of 565 GPS points per survey were collected on the Rossbeigh coastal barrier, in the summer of 2015, 2016, and 2017. These points were imported into ArcMap 10.6 to create and analyze a digital elevation map (DEM). In order to get a more representative model, bathymetric data is collected in the area on the seaward side of Rossbeigh, with special attention given to the ebb tidal bar (EBT) in front of the coastal barrier. This bar is formed by ebb tidal currents depositing material seawards of Rossbeigh. It plays an important role in circulation and sediment transport of the coastal cell. 
Bathymetry surveying was undertaken with a personal water craft (PWC) and using a LEICA Viva Rover GS08 GNSS system, in combination with a SonarM8 single beam echo sounder. The SonarM8 has a four-degree beam-width, works on a frequency of $200 \mathrm{kHz}$, and has a depth range between $0.3 \mathrm{~m}$ to $75 \mathrm{~m}$.

Good weather conditions are essential for fieldwork, as wind speed, wind direction, and swell impact data quality. Bathymetric surveys began during high tide, to cover a wider range. To minimize the error sources during surveying, bathymetry was only collected during calm conditions $\mathrm{Hs}<0.5 \mathrm{~m}$. This was based on field trials of single beam echo sounder PWC craft surveys recorded by [20] and [32]. Additionally, the accuracy of the points was dependent on the speed of the PWC. Therefore, a speed limit of $8-10 \mathrm{~km} / \mathrm{h}$ was maintained during surveys.

Bathymetric surveys were undertaken in August 2015 and May 2019 during suitable conditions. The results of these surveys were then compared with a previous bathymetric survey carried out in August 2013 [20].

\subsection{Storm Events}

In order to define a storm that affects the morphology in the surrounding area of the Rossbeigh coastal barrier, it was decided to use several thresholds for different parameters. Hourly data was available from a nearby weather station: Valentia Observatory $\left(51^{\circ} 56^{\prime} 23^{\prime \prime} \mathrm{N}, 10^{\circ} 14^{\prime} 40^{\prime \prime} \mathrm{W}\right)$ (Met Eireann, 2019), providing data for: (1) wind speed, (2) wind direction, and (3) atmospheric pressure. In addition, historical tidal data was generated using a toolbox available in MIKE 21. In situ sea level heights were collected over a period of one month (March 2006-April 2006) using a tidal gauge. The data was collected on Cape Clear, Ireland, located $75 \mathrm{~km}$ south of the study area. The data was then extrapolated using the MIKE 21 Global Tide Model in order to get sea level height from 1995 until 2019.

Firstly, the threshold for wind speed was set at 20 knots. On the Beaufort scale, this corresponds to "fresh breeze", with a wave height of 2-3 m and crested wavelets that form on inland waters. As such, 20 knots was considered a threshold that produces waves that will impact the morphology in the coastal cell of Dingle Bay. Secondly, the threshold for wind direction was set at 225-315 degrees. This interval was chosen because Dingle Bay is only affected by storms from this angle due to the topography of the bay, as discussed earlier. Furthermore, the threshold for atmospheric pressure was 990 mbar, as storm events are associated with low pressure areas. Lastly, the threshold for water level was set for water levels above mean sea level for a given period. In addition, a winter/summer split was chosen in order to see if the recovering period, during the summer, was sufficient enough (winter from 1 October-31 March and summer from 1 April-30 September).

In summary, if the wind speed was, for at least one hour, above 20 knots and came from a south-western direction, in combination with an atmospheric pressure below $990 \mathrm{mbar}$ and tides above mean sea level, it was considered a significant storm event. The total amount of storm events and the durations of single storm events occurring in the study area had an impact on the morphology of the coastal cell and drove both the nature and magnitude of the changes incident on the Rossbeigh coastal barrier.

\section{Results}

The dune vegetation lines were used for the analysis of the changes prevalent on the coastal barrier in Rossbeigh. The change of the vegetation lines prior to and after the breaching event is highlighted in Figure 3. These reference lines were used as a reference to examine the extent of the breached area and to undertake quantitative analysis of: (1) the extent of the vegetated dunes on Rossbeigh, (2) the width of the breached area, and (3) the quantity of the erosion on the coastal barrier. 


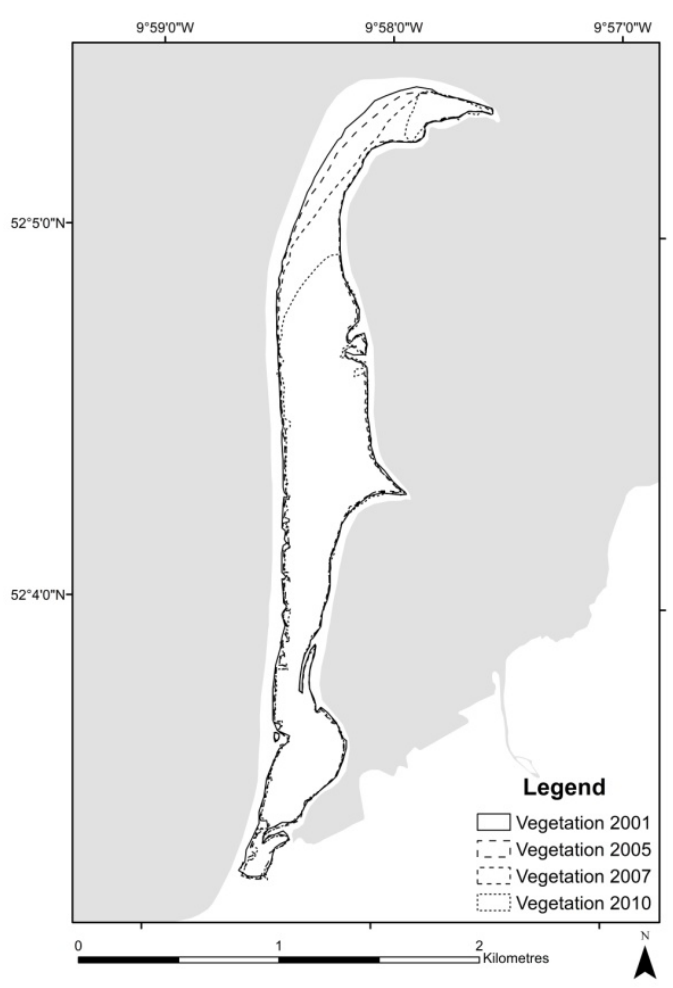

Figure 3. Vegetation alignment of Rossbeigh.

From 2005 onwards, it was clear that erosion was taking place in the drift-aligned zone of the coastal barrier, as the extent of the vegetation was getting narrower towards 2007. In the winter of 2008/2009, overwash led to the breach of the dunes in the drift-aligned zone due to continuous erosion of the previous years. The post-breach vegetation lines are highlighted in Figure 3, revealing the extent of erosion. This was mainly prevalent in the drift-aligned zone in 2010 and 2012, and from 2015 onwards, also in the swash-aligned zone. The extent of the vegetation located on the coastal barrier was observed growing for the first time between 2018 and 2019 since the erosion cycle started in 2001.

A quantitative summary of the depletion of the area of vegetation on the coastal barrier and its dune system can be seen in Table 2. Initially, the total area of vegetated dunes was $1.18 \mathrm{~km}^{2}$ in 2001 . Before the breach in 2008/2009, erosion already had led to a decrease of around $17 \%$ to a total area of $1 \mathrm{~km}^{2}$. After 18 years, a total decrease of $43.2 \%$ of the vegetated dunes on the Rossbeigh coastal barrier was apparent.

Table 2. Change in dune area on the coastal barrier from 2001-2019.

\begin{tabular}{ccc}
\hline Year & $\begin{array}{c}\text { Vegetated Area } \\
\mathbf{( k m}^{\mathbf{2}} \mathbf{)}\end{array}$ & $\begin{array}{c}\text { Percentage Change } \\
\mathbf{( \% )}\end{array}$ \\
\hline 2001 & 1.18 & \\
2005 & 1.10 & -7.0 \\
2007 & 0.99 & -10.4 \\
2010 & 0.89 & -12.1 \\
2012 & 0.78 & -13.6 \\
2015 & 0.71 & -10.4 \\
2017 & 0.68 & -3.3 \\
2018 & 0.65 & -5.1 \\
2019 & 0.67 & +2.27 \\
Total & $-\mathbf{0 . 5 1}$ & -43.2 \\
\hline
\end{tabular}


Table 3 shows the width of the breached area. Over nine years (2009-2018), the width of the breached area tripled from $325 \mathrm{~m}$ in 2009 to a maximum of $1025 \mathrm{~m}$ in 2018, a corresponding gradual decrease of the erosion on the coastal barrier is evident also.

Table 3. Width breached area Rossbeigh.

\begin{tabular}{cc}
\hline Year & Length $(\mathbf{m})$ \\
\hline 2009 (Sala, 2010) & 325 \\
2010 & 670 \\
2012 & 845 \\
2013 (O'Shea, 2013) & 900 \\
2015 & 985 \\
2017 & 1015 \\
2018 & 1025 \\
2019 & 1018 \\
\hline
\end{tabular}

As stated earlier, the average dune height ranged between 8-12 $\mathrm{m}$. This is, however, a simplification of the reality, as the height of the dunes was lower in the vicinity of the breach and higher in the swash-aligned zone. Indeed, the dune height exceeded the height of $15 \mathrm{~m}$ in some parts and decreased to around $5 \mathrm{~m}$ close to the breached area. Hence, two different calculations were undertaken for the volumetric change on the coastal barrier (i.e., dune height of $8 \mathrm{~m}$ and a dune height of $12 \mathrm{~m}$ ). An overview of the volumetric changes since 2001 can be seen in Table 4 .

Table 4. Volumetric change Rossbeigh.

\begin{tabular}{ccccc}
\hline Year & $\begin{array}{c}\text { Volume } \\
\text { Vegetated } \\
\text { Dunes-8 } \mathbf{~ m}\left(\mathbf{m}^{\mathbf{3}}\right)\end{array}$ & $\begin{array}{c}\text { Volume Vegetated } \\
\text { Dunes-12 } \mathbf{~} \mathbf{( m}^{\mathbf{3}} \mathbf{)}\end{array}$ & $\begin{array}{c}\text { Volume Change } \\
\left.\mathbf{8} \mathbf{~ m} \mathbf{( m}^{\mathbf{3}}\right)\end{array}$ & $\begin{array}{c}\text { Volume Change } \\
\mathbf{1 2} \mathbf{~ m}\left(\mathbf{m}^{\mathbf{3}}\right)\end{array}$ \\
\hline 2001 & $9,448,480$ & $14,172,720$ & - & - \\
2005 & $8,830,320$ & $13,245,480$ & $-618,160$ & $-927,240$ \\
2007 & $7,998,080$ & $11,997,120$ & $-832,240$ & $-1,248,360$ \\
2010 & $7,137,400$ & $10,706,100$ & $-860,680$ & $-1,291,020$ \\
2012 & $6,282,792$ & $9,424,188$ & $-854,608$ & $-1,281,912$ \\
2015 & $5,660,376$ & $8,490,564$ & $-622,416$ & $-933,624$ \\
2017 & $5,374,720$ & $8,062,080$ & $-285,656$ & $-428,484$ \\
2018 & $5,240,744$ & $7,861,116$ & $-266,088$ & $-99,132$ \\
2019 & $5,362,672$ & $8,044,008$ & $+121,928$ & $+182,892$ \\
Total & - & - & $\mathbf{4 , 0 8 4 , 1 4 4}$ & $\mathbf{6 , 1 2 6 , 2 1 6}$ \\
\hline
\end{tabular}

In 2001, the total volume of sediment available in the dunes of the coastal barrier was between 9.4-14.1 million $\mathrm{m}^{3}$. 18 years later, a total volume of between 4-6.1 million $\mathrm{m}^{3}$ sediment was eroded from Rossbeigh. At its lowest point in 2018, the total volume of sediment in the dunes was between 5.2-7.8 million $\mathrm{m}^{3}$.

It is clear from these results (Figures 2 and 3, and Table 2) that the vegetated dune area significantly decreased when the pre-breached (i.e., 2001-2007) situation is compared with the post-breached situation (i.e., 2010-2019).

Apart from the continuous erosion on the coastal barrier, Rossbeigh is also subject to a change in orientation manifesting as macro-cannibalization. This is mainly seen on the drift-aligned zone, whilst the swash-aligned zone is more or less in a state of dynamic equilibrium. The change of orientation can be seen in Figure 4 for 2001- 2018 (no significant change is visible between 2018 and 2019, so 2019 is not included). 


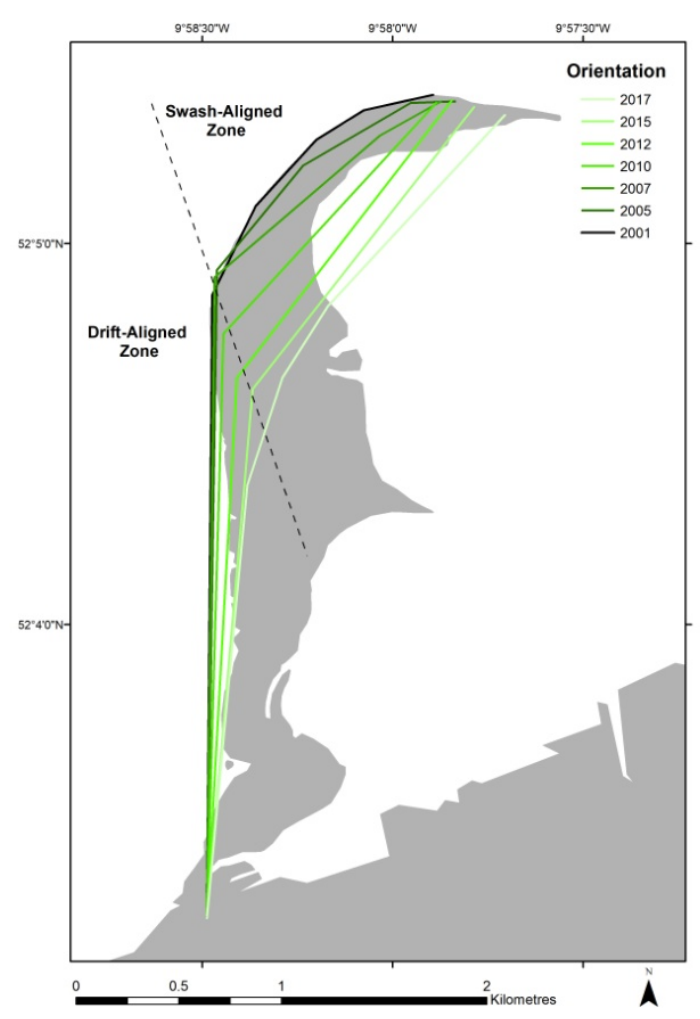

Figure 4. Progression from pre- to post-breach orientation of zones on Rossbeigh.

In addition to the alteration in orientation, the point where the swash-aligned zone shifts to the drift-aligned zone is also moving. The point between those two zones is described as the "Hinge Point" and is defined by the visual change in orientation from the satellite images. Comparison of the Hinge Point location from 2001 - 2019 are compared in Figure 5. It is clear that the Hinge Point was migrating in a northern direction before the breach. However, after the breaching event in 2008, the Hinge Point started moving to the south-east. By May 2018, the Hinge Point moved almost $450 \mathrm{~m}$ south and around $80 \mathrm{~m}$ east, compared to July 2001. From 2017, there is no clear point visible between the two zones and a "Transition Zone" between the drift-aligned and swash-aligned zone has emerged. The EBT, located on the seaward side of the coastal barrier, is increasing in size and moving towards the coastal barrier. The EBT reached the coastal barrier where it was located in 2001. However, because of the change in orientation, the EBT is still some distance away from the current position of the coastal barrier. There is a difference between the northern and southern part of the bar, with more stable conditions in the north. Moreover, the depth of the seabed was increasing in the north and decreasing in the south, highlighting sediment movement in the channel towards the tidal inlet in Dingle Bay. 


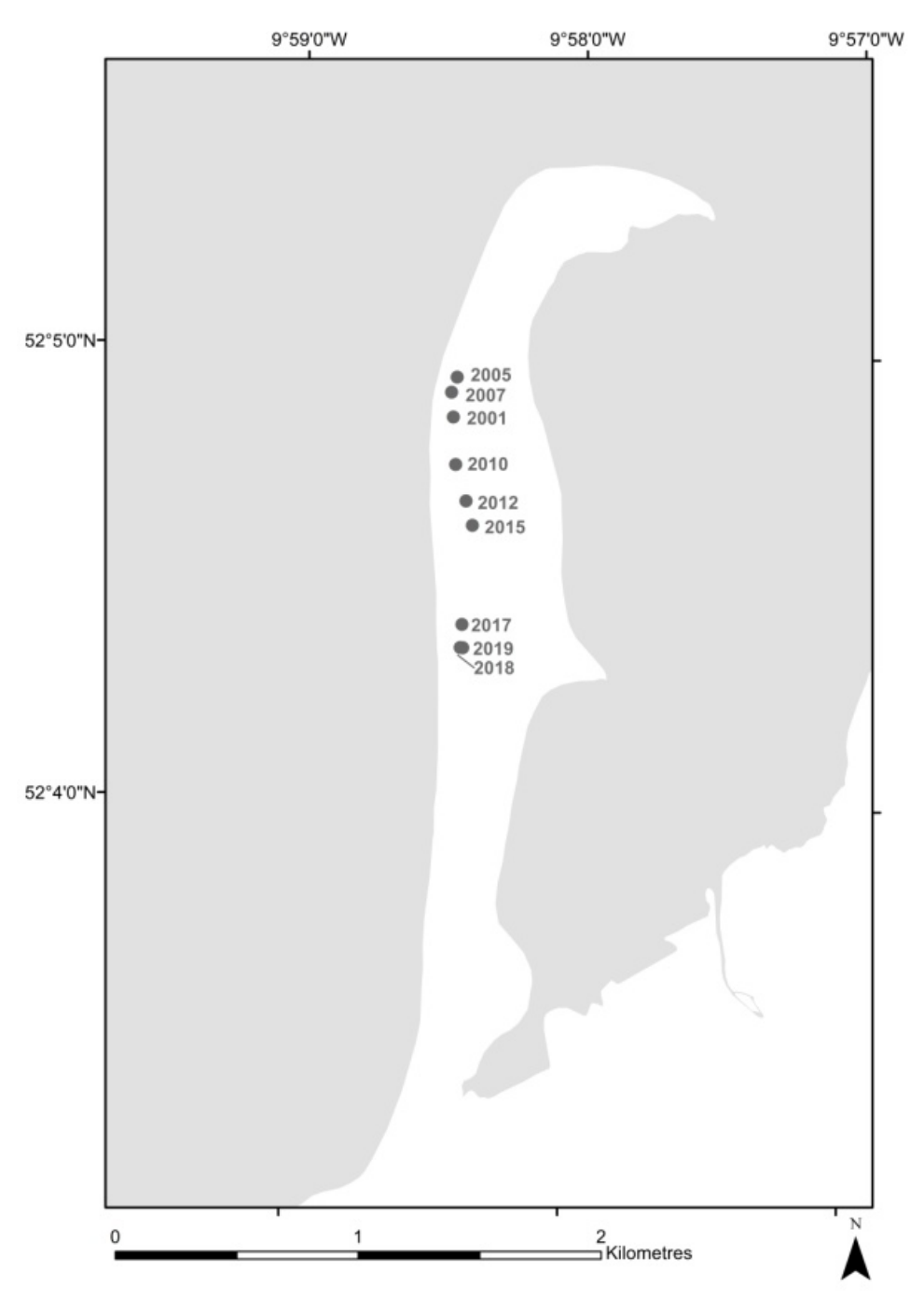

Figure 5. Hinge point migration.

A cross section analysis of the littoral zone, Figure 6 highlights the change of the EBT over time. The analysis was carried out using the different bathymetric surveys. The channel between the EBT and the coastal barrier was migrating, as can be seen from the profiles from the successive bathymetric surveys. Section A-A, at the northern end of this channel, shows that the offshore tidal bar has been migrating towards the drift-aligned zone. The deepest part of the channel between the shore and bar migrated eastwards between 2013 and 2015. With the shoreward progression of the EBT, tidal currents are forced through a narrowing channel (i.e., the channel gets smaller over time). Examining the trend further south, Sections B-B and C-C, it is evident that the channel has been filling in rapidly compared to A-A. This was likely due to the larger wetted perimeter and the larger distance between the EBT and the drift-aligned zone in these locations. The profile is flatter, and the tidal current has a larger if shallower cross-sectional flow area to pass through. By comparison the more northerly section A-A is deeper but narrower and more dynamic. 

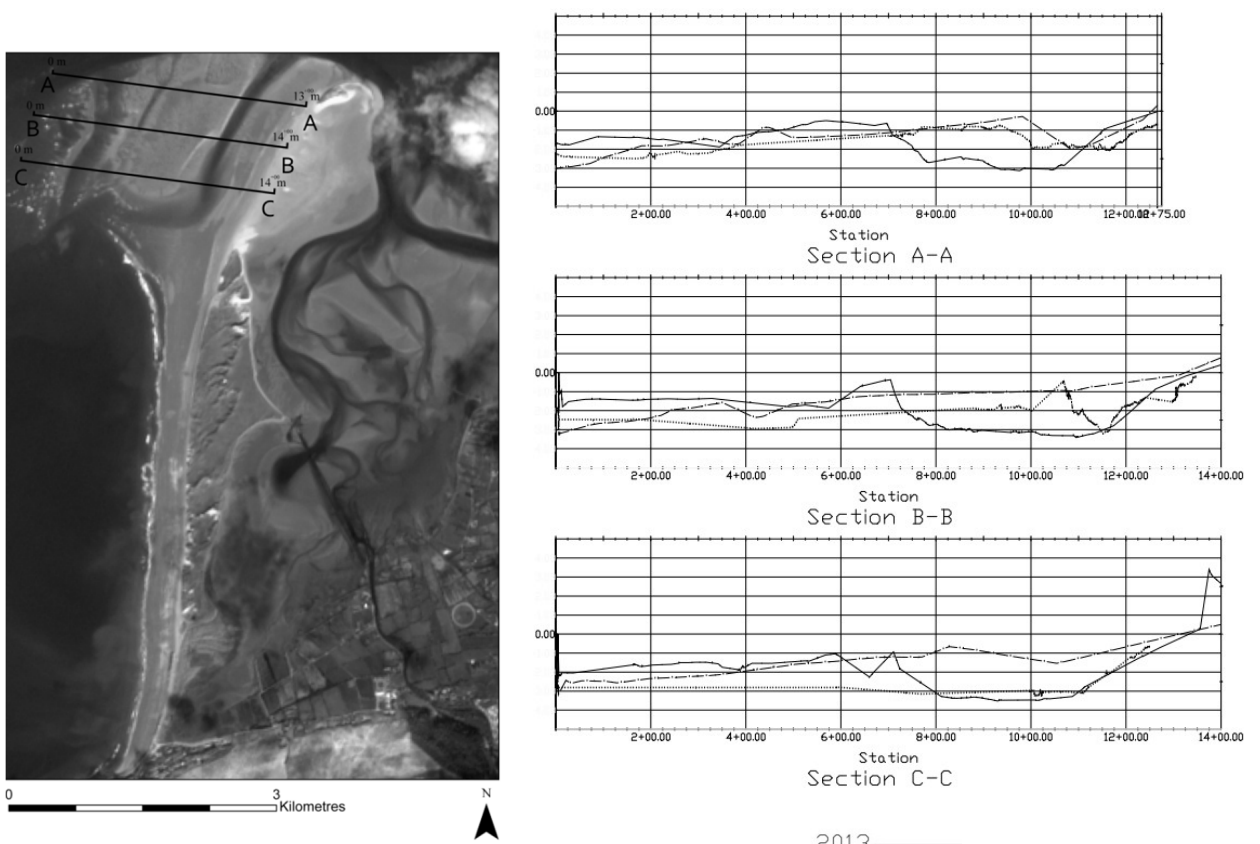

Section B-B

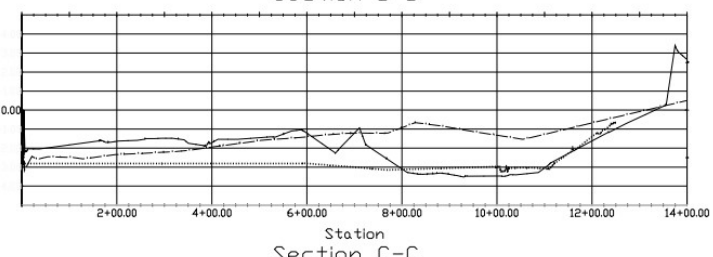

Section $C-C$

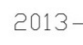

2015

$2019-\cdots$

Figure 6. Survey cross section comparison.

The adjustment of the coastline can arise during a single storm event or during a series of closely spaced storm events. Extreme weather events occurring in the study area in the late 1990s' and early 2000s' were likely the cause of the erosion rates that occurred on the coastal barrier of Rossbeigh. Figure 7 highlights the number of storm events from winter 1994/1995 to the summer of 2019, based on the thresholds discussed earlier. These storms were analyzed more specifically in relation to their potential impact on morphodynamics on Rossbeigh by calculating the average duration of an individual storm event, Figure 8, and the total duration of all storm events in a given season, Figure 9.

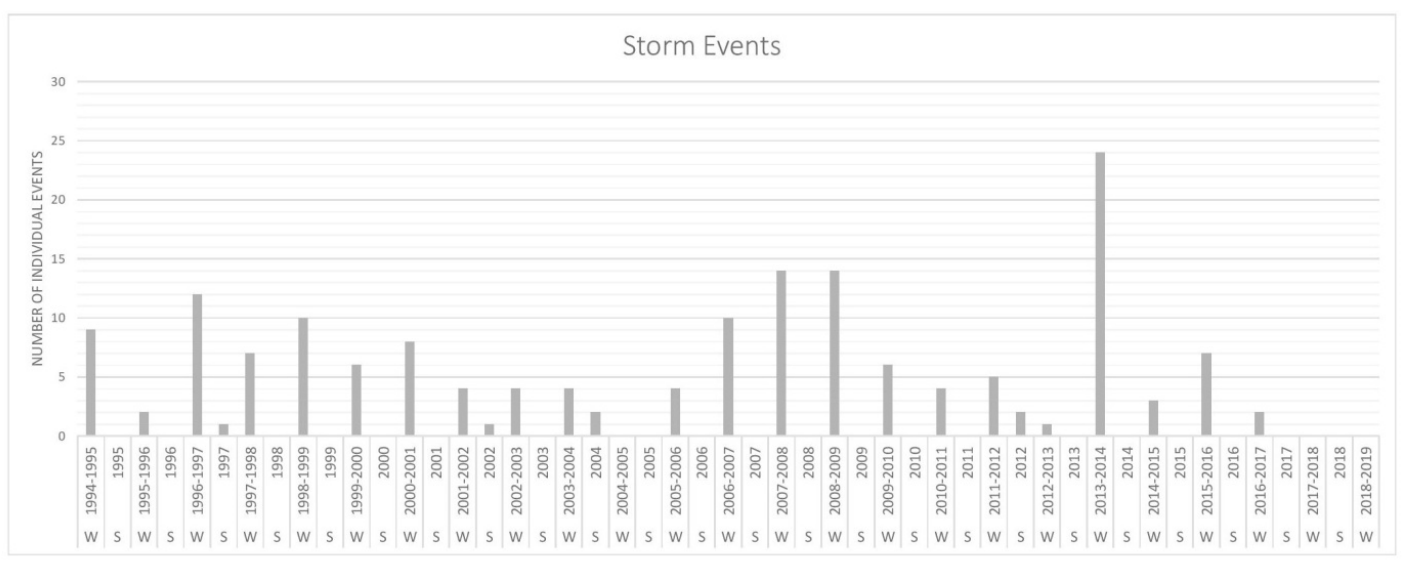

Figure 7. Number of storm events in the preceding 25 years incident on Dingle Bay. 


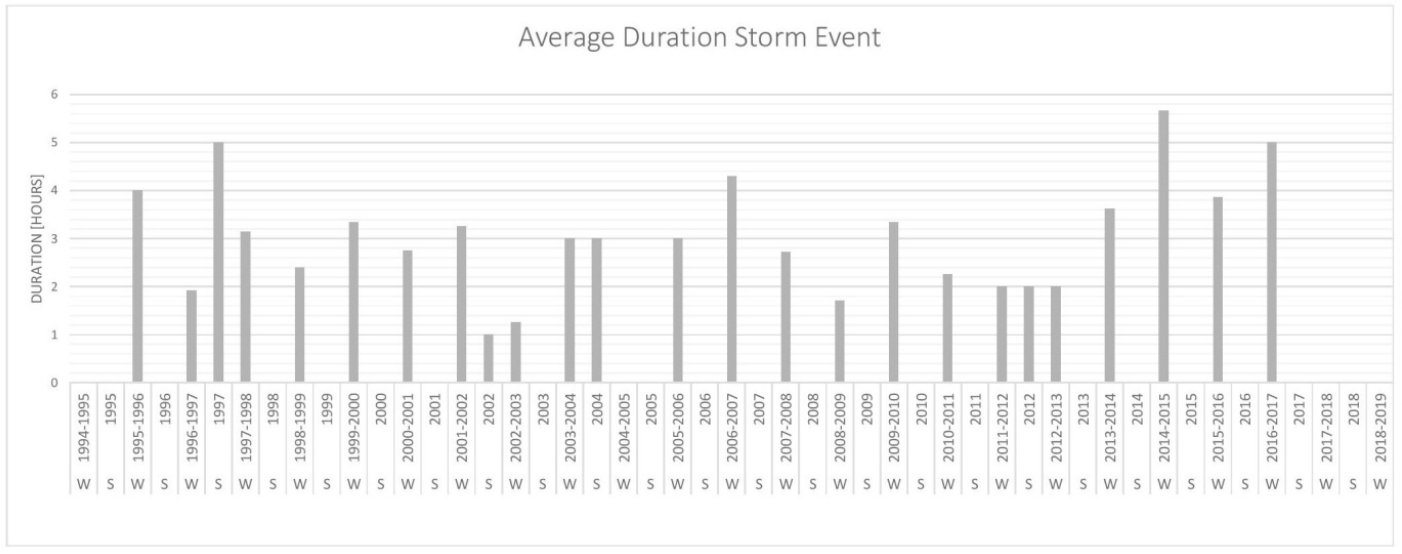

Figure 8. Mean storm durations in the preceding 25 years incident on Dingle Bay.

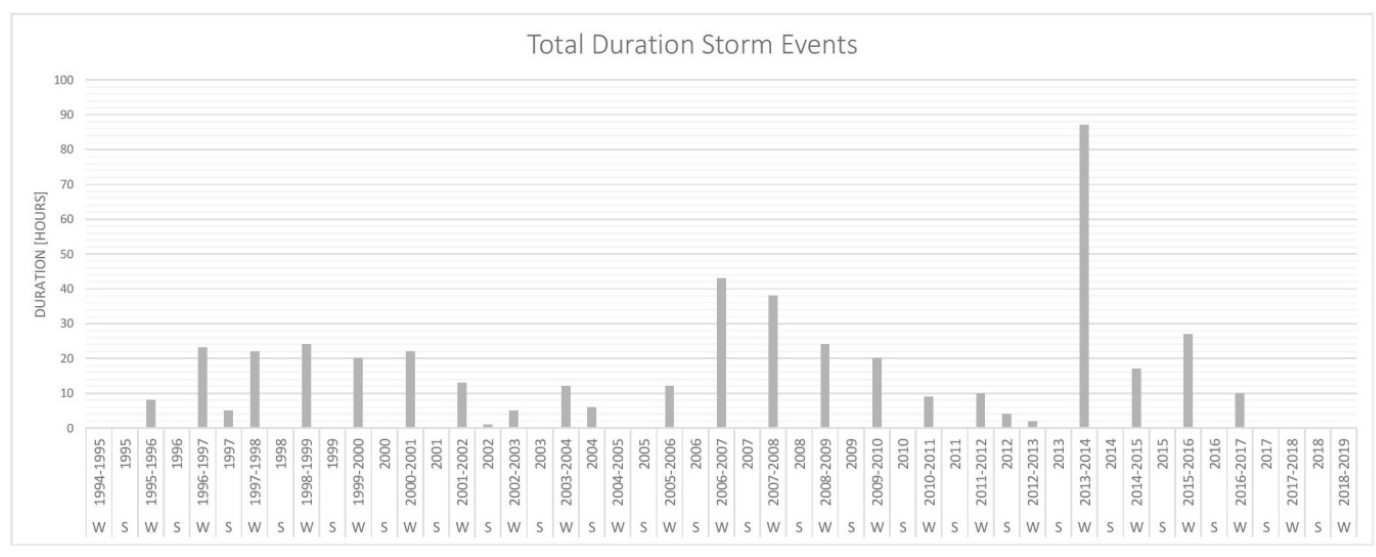

Figure 9. Total duration of storm events in the preceding 25 years incident on Dingle Bay.

It is clear that, prior to 2001, a significant amount of winter storms occurred. These events were probably the trigger that led to the destabilization of the morphology in the study area and the start of the erosion events. Before the breaching event, there was another peak in storm events, arguing that they are eventually the cause of the breach and overwash. Afterwards, another peak in storm events is visible in the winter of 2013-2014.

\section{Discussion}

Over the last 19 years (2001-2019), significant erosion has taken place on the Rossbeigh coastal barrier and its dunes. The erosion cycle that started in the early 2000s led to the current breaching event, which was caused by overwash, due to forcings from the western seaward side [18]. Atypical from other tidal inlets that are formed through breaching, the inlet that formed on the Rossbeigh coastal barrier is still open 10 years after the breaching event [33], and indicates that tidal inlets formed due to breaching should be able to heal over the years. It is clear, however, that until 2018, this system still had to attain some form of post-breaching equilibrium, as little or no seasonal recovery was visible during the time of observation and cannibalization was ongoing for a long period after the breaching event. The first signs of recovery are visible in 2019. For the first time since the breaching event, the vegetated area of the dunes is growing.

The growth of the EBT and the movement of that bar towards the coastal barrier suggest that the sediment eroded over the years during the cannibalization process will fill the channel fronting the Rossbeigh coastal barrier. We argue that this will eventually lead to the healing of the breach and will result in the possible restoration of the dune system prevalent on the coastal barrier prior to the erosion cycle characterized by micro- and macro-cannibalization that dominated since beginning of 
this century. Prior to 2017, there was no documented evidence that such a phase had commenced; the analysis of both remotely sensed data and the bathymetric survey shows that there is a clear migration trend of the EBT. The present study has confirmed that the EBT was moving eastwards towards the drift-aligned zone, from as early as April 2015. The analysis of this study also shows that the bar is in the position where the Rossbeigh coastal barrier was located in 2001.

Since the summer of 2017, marram grass has started to colonize areas in the breached area. This suggests that more stable conditions around the coastal cell of Rossbeigh favor the healing of the breach. Although, the erosion and the breached area was still increasing in 2018, signs of recovery were finally visible from 2019. This is likely linked with the growth of the EBT, which now covers the whole area in front of the breached area. This means that the impact of the open ocean forcings has decreased, and larger waves are not reaching this vulnerable section of the coastal barrier anymore. In addition, the analysis of the storms indicates a milder climate incident on the barrier beach compared to that of the large storm events that were previously occurring in the area. The conditions were more favorable in the last two years, 2017 and 2018, allowing breach healing now. If the EBT continues to grow, we argue that breach healing will occur in five years, with dune establishment to commence thereafter.

The change in orientation and the movement of the hinge point in a south-eastern direction shows that the swash-aligned zone is still decreasing. It is obvious from the figures highlighted in this study that there is a growing drift-aligned zone at the expense of the more stable swash-aligned zone. As the drift-aligned zone continues to grow, it is expected that macro-cannibalization will be ongoing. The decrease of the swash-aligned zone has left the growing drift-aligned zone and transition zone of the coastal barrier more vulnerable to wave action, as this part is not protected by the EBT. As such, the foredunes prevalent near the hinge point (i.e., the foredunes in the vicinity of the breached area) are subject to increased erosion and are particularly vulnerable during storm events.

This was especially visible between 2017 and 2018, where the swash aligned zone was clearly eroding as well. However, there is no distinct difference anymore between the swash-aligned zone and the drift-aligned zone. The transition zone between the swash-aligned zone and the drift-aligned zone is growing, which leads to a decrease in the swash-aligned zone. Hence, it can be argued that micro-cannibalization will eventually end, which will lead to the regeneration of the Rossbeigh coastal barrier and its dune systems. However, it is still unclear how macro-cannibalization will evolve over time, making it a highly dynamic and unpredictable system.

\section{Storm Events}

The morphological response of the beach profile is slower compared to the faster variation of the hydrodynamic forcing. As such, recovery, or the lack thereof, can extend far beyond a single season [34]. Changes in the morphology caused by storm events are often reversible if the system repairs itself during normal conditions. The changes in Rossbeigh, however, could be irreversible if the new morphology changes the sediment transport regime and the hydrodynamics of the system to such an extent that recovery is impossible within an immediate timeframe (i.e., less than decadal).

Kandrot, S. et al. [35] argues that storm events occurring in the study area are responsible for the delay and/or prevention of such beach healing. Storm events occur frequently in the southwest of Ireland. Studies $[3,26,36]$ have shown that storm events can have a significant impact on the sediment budgets of barrier systems. In this regard, the morphodynamics within such systems are dependent on the seasonal behavior of the tidal inlet, which is mainly affected by storm events.

The absence of big storm events in the last seasons and the recovery of the dune system in 2019 support this theory. The analysis of the channel between EBT and drift aligned shore suggests that such storm events may force accelerated migration of the EBT. This shoreward migration has been shown as a potential mechanism of breach healing. It is proposed that storm driven shoreward sediment transport could close the channel. The rate of closure of the channel is shown to have accelerated between 2013 and 2015, which corresponds to the frequent storm events in 2014. This channel closure acceleration is clearly visible in Section A-A of Figure 7 over that period. During the intervening period 
since 2015, storms have been more infrequent and channel closure and migration rates have stabilized. It is possible a further increase period of storm activity similar of 2014 is required to provide the final closure of the channel and have the EBT weld to the drift aligned shore. This would lead to a step change in the migration of the EBT, and beach healing could occur rapidly thereafter in the absence of regular scouring that the tidal channel is currently providing. The observed accretion rate would increase and allow aeolian transport and dune vegetation restorative processes to initiate dune regeneration. In this regard, continuous monitoring of the system is important in order to highlight the change over time of a natural breaching event.

\section{Conclusions}

It is clear from the examination of 19 years of remotely sensed data combined with field measurements that the Rossbeigh coastal barrier was in a post-breaching phase for the majority of the monitoring period. However, analysis of the dataset signifies that the system is capable of reaching a post-breaching equilibrium. This work identifies tangible processes that are occurring (e.g., movement of the EBT towards the coastal barrier and colonization of marram crass in the breached area) that indicate regrowth and breach healing is possible under the right circumstances (e.g., the protection of open ocean forcings by the EBT). The role of storm events within the study area suggests that while the system has not yet been able to reach a full beach-healing phase, a mechanism for such healing has been identified.

It is proposed that the regenerative gains observed during calm conditions are temporary and that further storm driven dune erosion is likely until such time as the EBT welds to the drift aligned shore. The storm events may play an important role in this process, as they mobilize large volumes of sediment. It is proposed that a step change is required to overcome the established tidal current regime that is preventing full migration and welding of the EBT to the drift aligned shore. A significant storm or series of storm events would provide the step change required for the system to enter a new cycle of growth and breach healing. It is vital therefore to map and monitor the different changes that occur on such systems in order to develop a clear understanding of the long-term behavior of coastal barriers and how the evolutionary phases transition from erosive to accretive.

\section{Further Research}

Regular data collection and analysis makes it possible to make predictions on the evolution of the coastal barrier in Rossbeigh and its surrounding coastal cell. In this regard, it is suggested to do follow-up surveys in order to get datasets with high temporal and spatial accuracy. This will lead to a more detailed analysis and to more accurate predictions.

It is necessary to achieve a complete understanding of the coastal processes in the study area before any human intervention is undertaken. This confirms the necessity of this research and future studies in Rossbeigh and its surrounding coastal cell. It is suggested to carry out a grain size trend analysis which associates grain sizes with sediment transport pathways on the Rossbeigh coastal barrier. This study would be similar in nature to the previous exercise by [18] but on a wider geographic scale over several seasons. Lastly, other results highlighted in this research (e.g., location of hinge points) were not analyzed in detail. A numerical analysis of zone orientation and hinge point location combined, including a curve fitting exercise to the shoreline, could provide further insight. This opens up possibilities with establishing mathematical relationships for the evolution such as second derivatives. Furthermore, the historical analysis undertaken on Rossbeigh and Inch in previous studies could be reanalyzed with such a mathematical approach. If such work is to be carried out the information produced in this study will form an essential baseline.

Author Contributions: Conceptualization, S.N.; methodology, S.N. and M.O.; software, S.N. and M.O.; investigation, S.N. and M.O.; writing—original draft preparation, S.N.; writing-review and editing, J.M.; visualization, S.N.; and supervision, J.M. All authors have read and agreed to the published version of the manuscript. 
Funding: This research received no external funding.

Conflicts of Interest: The authors declare no conflict of interest.

\section{References}

1. Saye, S.E.; Pye, K. Implications of sea level rise for coastal dune habitat conservation in Wales, UK. J. Coast. Conserv. 2007, 11, 31-52. [CrossRef]

2. Blott, S.J.; Pye, K. Particle shape: A review and new methods of characterization and classification. Sedimentology 2008, 55, 31-63. [CrossRef]

3. O'Shea, M.; Murphy, J.; Sala, P. Monitoring the morphodynamic behaviour of a breached barrier beach system and its impacts on an estuarine system. In Proceedings of the 2011 IEEE OCEANS, Santander, Spain, 6-9 June 2011; pp. 1-8.

4. Chadwick, A.; Karunarathna, H.; Gehrels, W.; Massey, A.; O’brien, D.; Dales, D. A new analysis of the Slapton barrier beach system, UK. Proc. ICE-Marit. Eng. 2005, 158, 147-161. [CrossRef]

5. Freeman, C.W.; Bernstein, D.J.; Mitasova, H. Rapid response 3D survey techniques for seamless topo/bathy modelling: 2003 Hatteras Breach, North Carolina. Shore Beach 2004, 72, 25-29.

6. Gracia, V.; García, M.; Grifoll, M.; Sánchez-Arcilla, A. Breaching of a barrier beach under extreme events. The role of morphodynamic simulations. J. Coast. Res. 2013, 65, 951-956.

7. Terchunian, A.; Merkert, C. Little Pikes Inlet, Westhampton, New York. J. Coast. Res. 1995, 11, $697-703$.

8. Tsoar, H.; Levin, N.; Porat, N.; Maia, L.P.; Herrmann, H.J.; Tatumi, S.H.; Claudino-Sales, V. The effect of climate change on the mobility and stability of coastal sand dunes in Ceará State (NE Brazil). Quat. Res. 2009, 71, 217-226. [CrossRef]

9. Nickling, W.G.; Davidson-Arnott, R.G. Aeolian Sediment Transport on Beached and Coastal Dunes. Proceedings Symposium on Coastal Sand Dunes; NRC: Ottawa, ON, Canada, 1990; pp. 1-35.

10. Ritchie, W.; Penland, S. Rapid dune changes associated with overwash processes on the deltaic coast of South Louisiana. Mar. Geol. 1988, 81, 97-122. [CrossRef]

11. Arens, S.M. Rates of aeolian transport on a beach in a temperate humid climate. Geomorphology 1996, 17, 3-18. [CrossRef]

12. O'Shea, M.; Murphy, J. Investigating the Hydrodynamics of a Breached Barrier Beach. EGU Gen. Assem. Conf. Abstr. 2011, 14, 43.

13. Edelman, T. Dune Erosion During Storm Conditions. In Proceedings of the 11th Conference on Coastal Engineering, London, UK, September 1968; American Society of Civil Engineers: Reston, VA, USA; Volume 2, pp. 719-722. [CrossRef]

14. Vellinga, P. Beach and dune erosion during storm surges. Coast. Eng. 1982, 6, 361-387. [CrossRef]

15. van de Graaff, J. Dune erosion during a storm surge. Coast. Eng. 1977, 1, 99-134. [CrossRef]

16. Steetzel Henk, J. Cross-Shore Transport during Storm Surges. Coast. Eng. 1990, 1991, 1922-1934. [CrossRef]

17. Orford, J.D.; Carter, R.W.G.; Jennings, S.C. Control Domains and Morphological Phases in Gravel-Dominated Coastal Barriers of Nova Scotia. J. Coast. Res. 1996, 12, 589-604.

18. Gault, J.; O'Hagan, A.M.; Cummins, V.; Murphy, J.; Vial, T. Erosion management in Inch beach, South West Ireland. Ocean Coast. Manag. 2011, 54, 930-942. [CrossRef]

19. O'Shea, M. Monitoring and Modelling the Morphodynamic Evolution of a Breached Barrier Beach System. Ph.D. Thesis, University College Cork, Cork, Ireland, 2013.

20. FitzGerald, D.; Kraus, N.; Hands, E.B. Natural Mechanisms of Sediment Bypassing at Tidal Inlets; US Army Corps of Engineers: Vicksburg, MS, USA, 2000.

21. O'Shea, M.; Murphy, J. The Validation of a New GSTA Case in a Dynamic Coastal Environment Using Morphodynamic Modelling and Bathymetric Monitoring. J. Mar. Sci. Eng. 2016, 4, 27. [CrossRef]

22. Wintle, A.G.; Clarke, M.L.; Musson, F.M.; Orford, J.D.; Devoy, R.J.N. Luminescence dating of recent dunes on Inch Spit, Dingle Bay, southwest Ireland. Holocene 1998, 8, 331-339. [CrossRef]

23. Sala, P. Morphodynamic Evolution of a Tidal Inlet Mid-Bay Barrier System. Master's Thesis, University College Cork, Cork, Ireland, 2010; 226p.

24. Davies, J.L. Geographical Variation in Coastal Development, 2nd ed.; Longman: New York, NY, USA, 1980.

25. Haslett, S. Coastal Systems; Routledge: London, UK, 2008. 
26. Williams, J.J.; Esteves, L.S.; Rochford, L.A. Modelling storm responses on a high-energy coastline with XBeach. Modeling Earth Syst. Environ. 2015, 1, 3. [CrossRef]

27. Masselink, G.; Short, D.A. The Effect of Tide Range on Beach Morphodynamics and Morphology: A Conceptual Beach Model. J. Coast. Res. 1993, 9, 785-800.

28. Kraus, N.C.; Wamsley, T.V. Coastal Barrier Breaching. Part 1. Overview of Breaching Processes, Coastal and Hydraulics Engineering Technical Note ERDC/CHL CHETN-IV-56, US Army Corps of Engineers, Vicksburg, MS, USA, 2003. Available online: http://chl.wes.army.mil/library/publi-cations/chetn/pdf/chetn-iv-56.pdf (accessed on 28 March 2020).

29. Donnelly, C.; Kraus, N.; Larson, M. State of Knowledge on Measurement and Modeling of Coastal Overwash. J. Coast. Res. 2006, 965-991. [CrossRef]

30. Matias, A.; Williams, J.J.; Masselink, G.; Ferreira, Ó. Overwash threshold for gravel barriers. Coast. Eng. 2012, 63, 48-61. [CrossRef]

31. McCall, R.T.; Van Thiel de Vries, J.S.M.; Plant, N.G.; Van Dongeren, A.R.; Roelvink, J.A.; Thompson, D.M.; Reniers, A.J.H.M. Two-dimensional time dependent hurricane overwash and erosion modeling at Santa Rosa Island. Coast. Eng. 2010, 57, 668-683. [CrossRef]

32. MacMahan, J. Hydrographic surveying from personal watercraft. J. Surv. Eng. 2001, 127, 12-24. [CrossRef]

33. Davis, R.; Fitzgerald, D. Beaches and Coasts; John Wiley and Sons: New York, NY, USA, 2004; 432p.

34. Larson, M.; Erikson, L.; Hanson, H. An analytical model to predict dune erosion due to wave impact. Coast. Eng. 2004, 51, 675-696. [CrossRef]

35. Kandrot, S.; Farrell, E.; Devoy, R. The morphological response of foredunes at a breached barrier system to winter 2013/2014 storms on the southwest coast of Ireland. Earth Surf. Process. Landf. 2016, 41, 2123-2136. [CrossRef]

36. Balouin, Y.; Howa, H. Sediment transport pattern at the Barra Nova inlet, south Portugal: A conceptual model. Geo-Mar. Lett. 2001, 21, 226-235. [CrossRef]

(C) 2020 by the authors. Licensee MDPI, Basel, Switzerland. This article is an open access article distributed under the terms and conditions of the Creative Commons Attribution (CC BY) license (http://creativecommons.org/licenses/by/4.0/). 